\title{
Risk of predation: a critical force driving habitat quality perception and foraging behavior of granivorous birds in a Nigerian forest reserve
}

\author{
Umarfarooq A. Abdulwahab ${ }^{1,2^{*}}$ (D) Samuel Temidayo Osinubi ${ }^{3}$ and Jacinta Abalaka
}

\begin{abstract}
Background: Understanding the factors that influence the foraging behavior and perception of habitat quality by animals has long been the focus in ecology. Due to the direct effect resource acquisition has on an individual's fitness and species' survival, predation risk is considered widely to be a major driver of foraging decision. The objectives of this study were to investigate how predation risk is perceived by granivorous bird species with respect to different habitat and microhabitat types, time of day and food types in Amurum Forest Reserve, Nigeria, with a view to direct future conservation planning.
\end{abstract}

Methods: For 3 months, we conducted field experiments to measure giving-up densities (GUD, the amount of food left behind in artificial patches after birds cease to forage in it) and how it differs with habitat types, microhabitats, times of day, and food types. General linear mixed-effect models (GLMMs) were fitted to investigate the differences in GUD with respect to the aforementioned variables. Model selection was done based on the Akaike's Information Criterion (AIC).

Results: There was no significant difference in GUDs across habitats. However, there was a significant difference in GUDs between microhabitats. Higher food remnants were recorded in the open than in cover microhabitats, as birds exploited food patches in the cover more. Time of day influenced foraging behavior in the birds. They foraged more in the morning than afternoon across all three habitats except for the gallery forest where birds foraged less in the morning. Higher GUDs were recorded in open than cover microhabitats both in the morning and the afternoon. Birds had a preference for rice, millet, and groundnut respectively.

Conclusion: The differences in GUDs were very indicative of differences in foraging behavior and perception of resource availability in response to perceived predation risk. Therefore, this study suggests that the understanding of foraging decisions can be a veritable method for assessing habitat quality as perceived by animals.

Keywords: Food availability, Foraging behavior, Giving-up density, Habitat quality, Predation risk

\footnotetext{
*Correspondence: farooqadavudi@gmail.com

${ }^{1}$ A. P. Leventis Ornithological Research Institute, University of Jos, Jos,

Plateau State, Nigeria

Full list of author information is available at the end of the article
} 


\section{Background}

The access and acquisition of resources have direct effects on the reproductive success and survival of animals (i.e. individual fitness; Lemon 1991; Stearns 1992; Roff 1993), eventually contributing to the regulation of animal populations (i.e. species fitness; Newton 1998; Kelly 1999). However, animals engaged in active foraging may experience a high risk of predation, because foraging activities can increase their period of exposure and visibility to predators and compromise their vigilance, and predators may favorably target foragers that are less vigilant and more susceptible (Higginson et al. 2012). Therefore, to maximize fitness, individuals have to be capable of accurately assessing the local risks of predation and engage in foraging behaviors that optimize energy intake (Kamil et al. 2012). When faced with predation risk, foragers can reduce their individual risk of predation by incorporating a number of anti-predatory behavior, such as increasing their vigilance, seeking hide-out or mobbing predators, changing their food choices, and fleeing (Stankowich and Blumstein 2005). Thus largely engaging in foraging behaviors that maximize energy intake while reducing predation risk. Additionally, animals' perception of habitat quality is much more than just predation risk. Other factors such as food availability, energy expenditure, and competition combine to define habitat quality for species as well as individuals. Therefore, foraging behavior often indicates a strong linkage to habitat conditions as perceived by the foraging animal (Wilmers et al. 2015).

The concept of habitat quality has a lasting history in biology and ecology, but despite its strong bases and growing usage in academic studies, researchers have not come to an agreement on the best way it should be assessed (Breckheimer 2012). Direct estimation of the quality of foraging habitat (food availability) or predation risk remains a formidable task in ecological studies. The goal is to estimate habitat quality 'through the eyes' of the organism since habitat quality is not absolute but rather species or individual specific (Morris and Davidson 2000). Optimal foraging theory provides a useful framework on animals' perception of habitat quality (Stephens and Krebs 1986). An animal behaving optimally quits foraging a patch when the marginal profits (i.e. energy gains) equal the marginal costs of foraging (e.g. predation cost of foraging, the metabolic cost of foraging, and missed opportunity costs of not engaging in alternative activities; Brown 1988).

As a food patch is gradually depleted, a forager receives diminishing returns, finding additional food items become increasingly difficult and the benefits of foraging in the patch no longer outweigh the costs, in which case the animal decides to leave the patch (Charnov 1976). A valuable behavioral tool used by ecologists in understanding differences in quality between habitats and takes into consideration other factors is the measurement of giving-up densities (GUD; Brown 1988; Olsson and Molokwu 2007). The GUD of a food patch is the density of food remaining in the patch after the animal stops to forage in it (Brown 1988). Consequently, GUD is an assessment of the foraging animal's decision, and hence its discernments of environmental quality and surrounding circumstances. Animals will leave a patch earlier in an environment of high quality where the cost of missed opportunities is high and the animal's fitness prospects are high; thereby creating a positive relationship between habitat quality, GUD, and fitness (Olsson and Molokwu 2007). Similarly, the potential cost of predation will also be high in a highquality habitat because of high fitness prospects and the low marginal value of energy.

It is possible to assess foraging costs in natural habitats by creating artificial patches containing a known density of resources and by measuring the GUDs in these patches after animals abandon them. This approach is based on the assumption that the forager balances its harvest rate in the artificial patch with habitat-specific foraging costs, thus effectively treating the artificial patch as part of the natural environment (Brown and Alkon 1990). Evaluation of habitat-specific elements of the cost function may consequently be possible either by comparing GUDs among habitats and speculating on the effects of structural differences on foraging costs imposed on the animal or by experimental manipulation of foraging costs (Kotler 1992).

Here, we tested the determinants of foraging decisions by granivorous birds through field experiments and observation in Amurum Forest Reserve, northcentral Nigeria. We specifically tested what factor(s) amongst habitat type (with close and open microhabitat conditions), time of day (morning and evening), and food type (millet, crushed rice, and crushed peanuts) influence habitat quality perception and foraging behavior in granivorous birds. We placed each of the three food types in cover (an area surrounded by bush or dense vegetation and shaded from sunlight) and in open (1.5 m away from surrounding bush, completely exposed to sunlight; Molokwu et al. 2008; Fig. 1). We hypothesized that feeding trays placed in cover would be utilized more than those in the open microhabitat, potentially because of the low perception of predation risk. Also, we hypothesized that birds would prefer food with high energy content and easily digestible. Finally, we hypothesized that birds would feed more in the morning session having metabolized the food taken during the day over the night. The results of this study would help to better understand how 


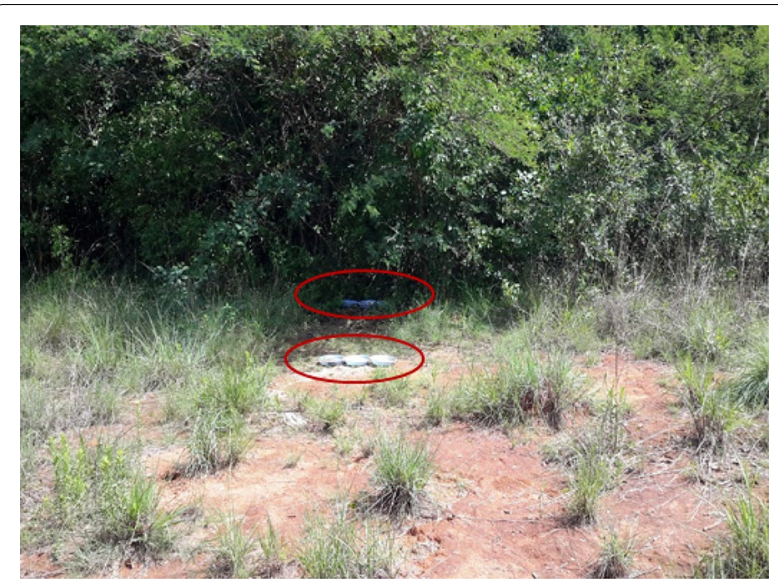

Fig. 1 Experimental set-up showing one of the sites in the Gallery forest

granivorous birds perceive habitat quality of the forest reserve and could potentially help inform future conservation planning.

\section{Methods}

\section{Study area}

The study was carried out in Amurum Forest Reserve with a total area of about 115 ha. It is located within the guinea savannah region northeast of Jos, northcentral Nigeria $\left(09^{\circ} 53^{\prime} \mathrm{N}, 08^{\circ} 59^{\prime} \mathrm{E}\right)$ and at an altitude of $1280 \mathrm{~m}$ above sea level (Vickery and Jones 2002). The reserve is recognized internationally as an Important Bird Area (IBA) with over 300 bird species (Mwansat et al. 2011). A wide range of granivorous birds species including the range-restricted Rock Firefinch (Lagonosticta sanguinodorsalis) and its brood parasite, the Jos Plateau Indigobird (Vidua maryae) utilize the reserve (Ezealor 2002). During the early wet season (between the end of May and the end of June), when grass seeds germinate, granivorous birds experience reduced food (grass seeds) availability (Molokwu et al. 2008). Grass seeds become available in high abundance at the end of wet season until the middle of the dry season when there is a progressive decline due to consumption by granivores. Most seeds germinate after the first few showers of rain resulting in even more reduced seed availability (Dostine and Franklin 2002). Fire outbreaks were a major incident just before the study started, which can potentially pose an adverse effect on food availability for granivorous birds.

The reserve is characterized by three habitat types, namely the gallery forests, savannah, and rocky outcrops. Two sites were selected in each of the three habitat types (Fig. 2), each being at least $200 \mathrm{~m}$ apart.

\section{Experimental set-up}

Within each of the two sites in each of the three habitats, two microhabitats were selected; 'cover' (under a bush or dense vegetation, completely sheltered from sunlight and potentially low predation risk), and 'open' ( $1.5 \mathrm{~m}$ away from surrounding bush, completely exposed to sunlight and with a potentially high predation risk; Molokwu et al. 2008; Fig. 2). Three feeding trays ( $4 \mathrm{~cm}$ deep and $26 \mathrm{~cm}$ in diameter) were placed side by side in each of the microhabitats in each site (Molokwu et al. 2008; Fig. 2). In each microhabitat, three feeding trays were provisioned with a mixture of sifted sand $(1 \mathrm{~L})$ and stocked with food $(7 \mathrm{~g}$ each of millet, crushed rice and crushed peanuts per tray). Rice and groundnut were crushed to approximately the same size as millet, so that food preference in birds will not be a result of the difference in seed size.

From February to April 2017, seeds were placed at each site to get the birds habituated to feeding at the feeding trays before the commencement of the experiments in May 2017. The experiment was set up in two sessions of the day-morning and afternoon, each lasting $5 \mathrm{~h}$. Morning sessions lasted from 06:30 to 11:30 and afternoon session lasted from 12:00 to 17:00. After every session, tray contents were collected in bags and later sifted to separate the sand from the seeds. The remaining seeds (defined here as GUDs) were weighed to the nearest $0.1 \mathrm{~g}$ using a digital weighing scale. All sites were visited daily (barring heavy rainfall) from Mondays to Fridays, making a total of 5 days a week of data collection. The whole experiment lasted for about 8 weeks (37 days) from May 29th, 2017 to July 24th, 2017. In all, there were 72 GUD records per day ( 6 feeding trays: three each in both cover and open microhabitats $\times 3$ habitat types $\times 2$ replicate sites $\times 2$ experimental sessions), making a total of 2664 records by the end of the experiment.

\section{Focal observations}

Sites were intermittently visited to record birds visiting the trays. Focal observations were done using a pair of binoculars at a minimum distance of $15 \mathrm{~m}$ from the trays in order to prevent any form of introduced disturbance. The underlining objective here is to document and compare the types of bird species visiting food trays to a similar experiment conducted in the reserve in 2004 and 2005 (Molokwu et al. 2008).

\section{Data analyses}

All statistical analyses were performed using $\mathrm{R}$ (Version 3.4.3, R Development Core Team 2017). Prior to analyses, we conducted a visual inspection of residual plots which did not reveal any obvious deviations from homoscedasticity or normality. We then applied general 


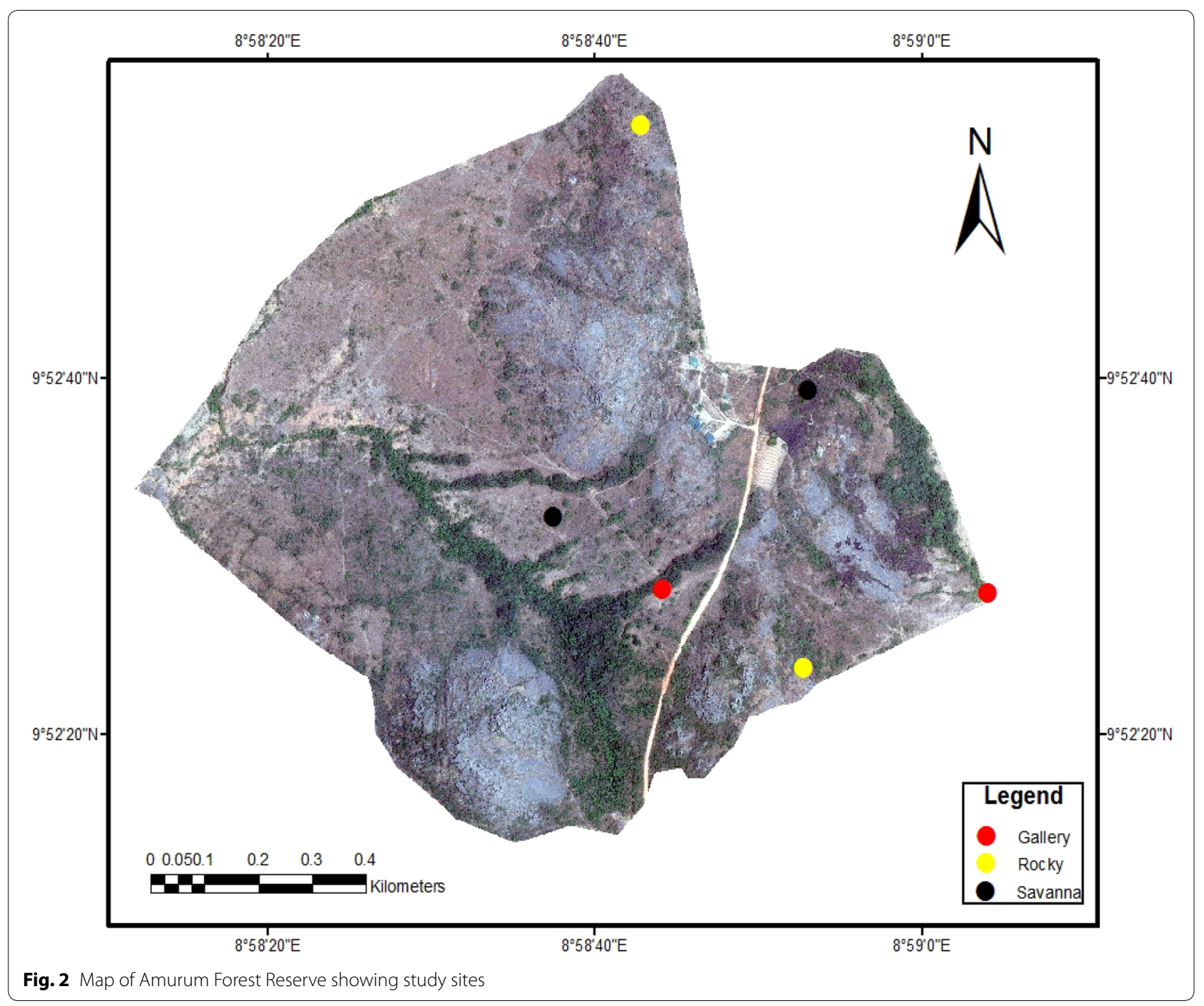

linear mixed-effect models (GLMMs) with lme function and then fitted in the nlme library package of $\mathrm{R}$ (Pinheiro et al. 2012). In the models fitted, the response variable was GUD while the explanatory variables include habitat types (gallery forest, rocky outcrop, and savannah), microhabitats ('cover' and 'open'), times of day (morning versus afternoon), and food types (groundnut, millet, and rice). We also tested for the interactions between habitat and microhabitat, habitat and time of day, and microhabitat and time of day on GUDs using maximum likelihood (ML) estimation method (Bolker et al. 2009). In this analysis, running days nested within sites were considered as random factors to correct for non-independence in the dataset. Models were compared with respect to their Akaike's Information Criterion (AIC; Burnham and Anderson 2002) values to select the model(s) best fit for the data. The model with the lowest AIC was considered to be the best. All models within 2 AIC units were considered competing models (Burnham and Anderson 2002). Variable importance was inferred through the comparison of standardized effect sizes (Schielzeth 2010). Where explanatory variables (main and interaction terms) were statistically significant, we performed posthoc tests using the package emmeans (Russell et al. 2018) to better understand where actual differences lie.

\section{Results}

\section{General linear mixed-effect model for GUD}

The best GUD model was one that had all the predictor variables as well as all three two-way interaction terms (Table 1). In this best model, the two-way interaction terms of habitat with microhabitat $\left(F_{2,2662}=46.72, P<0.0001\right)$, habitat with time of day $\left(F_{2,2662}=48.84, P<0.0001\right)$, microhabitat with time of day $\left(F_{1,2663}=8.90, P=0.0078\right)$, and fixed term-food type $\left(F_{2,2662}=315.33, P<0.0001\right)$ were all significant. In essence, the mass of left-over food is 
Table 1 GUD models with predictor variables

\begin{tabular}{|c|c|c|}
\hline GUD models & AIC & $\Delta \mathrm{AIC}$ \\
\hline $\begin{array}{l}\text { GUD } \sim \text { microhab + hab + timday + food type + hab*microhab + hab*timday + microhab*timday + (1|site/ } \\
\text { running days) }\end{array}$ & 10985.5 & 0.0 \\
\hline GUD $\sim$ microhab + hab + timday + food type + hab*microhabitat $+(1 /$ site/running days $)$ & 11079.6 & 94.1 \\
\hline GUD $\sim$ microhab + hab + timday + food type + microhab*timday + (1|site/running days $)$ & 11147.3 & 161.8 \\
\hline GUD $\sim$ microhabitat + habitat + time of day + food type + (1|site/running days $)$ & 11465.1 & 479.6 \\
\hline GUD $\sim$ microhab + hab + timday + (1|site/running days $)$ & 11601.5 & 616.0 \\
\hline GUD microhab + hab + (1|site/running days $)$ & 11654.7 & 669.2 \\
\hline GUD microhab + timday + (1|site/running days $)$ & 11683.2 & 697.7 \\
\hline GUD microhab + (1|site/running days $)$ & 11699.8 & 714.3 \\
\hline GUD hab + (1|site/running days $)$ & 11887.7 & 902.2 \\
\hline GUD $\sim$ timday + (1/site/running days $)$ & 11899.9 & 914.4 \\
\hline GUD $\sim 1+(1 \mid$ site/running days $)$ & 11925.3 & 939.8 \\
\hline
\end{tabular}

The terms 'Microb' $=$ microhabitat, ${ }^{\prime} \mathrm{Hab}^{\prime}=$ habitat, ${ }^{\prime}$ Timday' $=$ times of day, and ${ }^{\prime}\left(1 \mid\right.$ site/running days) ${ }^{\prime}=$ the running days nested within Site specified as a random factor. $\mathrm{AIC}=$ Akaike's Information Criterion values, $\triangle \mathrm{AIC}=$ the difference in $\mathrm{AIC}$ values. An asterisk * refers to an interaction term

Table 2 Result of posthoc tests for all statistically significant terms in the best model

\begin{tabular}{|c|c|c|c|c|c|}
\hline Significant variables & Contrast & Estimate & SE & $t$ ratio & $p$-value \\
\hline \multirow[t]{3}{*}{ Food type } & Groundnut $=$ millet & 0.389 & 0.071 & 5.937 & $<0.001$ \\
\hline & Groundnut $=$ rice & 1.589 & 0.066 & 24.235 & $<0.001$ \\
\hline & Millet $=$ rice & 1.200 & 0.058 & 18.298 & $<0.001$ \\
\hline \multirow[t]{3}{*}{ Hab*microhab } & Gallery forest: cover=open & -1.512 & 0.089 & 16.304 & $<0.001$ \\
\hline & Rocky outcrops: cover = open & -0.335 & 0.093 & -3.610 & $<0.001$ \\
\hline & Savannah: cover=open & -0.788 & 0.081 & -8.497 & $<0.001$ \\
\hline \multirow[t]{3}{*}{ Hab*timday } & Gallery forest: morning = afternoon & -0.049 & 0.063 & -0.524 & 0.601 \\
\hline & Rocky outcrops: morning = afternoon & -0.705 & 0.080 & -7.600 & $<0.001$ \\
\hline & Savannah: morning = afternoon & 0.530 & 0.098 & 5.714 & $<0.001$ \\
\hline \multirow[t]{2}{*}{ Microhab*timday } & Morning: cover = open & -0.739 & 0.086 & -9.576 & $<0.001$ \\
\hline & Afternoon: cover = open & -1.018 & 0.076 & -13.441 & $<0.001$ \\
\hline
\end{tabular}

a function of the interactions between habitat and microhabitat, habitat and time of day, microhabitat and time of day, as well as the fixed effect of food type.

Broadly, a posthoc test showed that GUD was consistently higher in the 'open' than in the 'cover' across all three habitat types (Table 2, Fig. 3). GUDs were significantly lower in the mornings than afternoons for the rocky outcrop and savannah habitats. However, there was no significant difference in GUD between times of day in the gallery forest, even though GUD appear to be slightly lower in the afternoons than mornings (Table 2, Fig. 4). GUDs in the 'open' microhabitat were relatively higher than 'cover' microhabitat across the times of day (Fig. 5). There was a consistent preference for the cereal grains with rice being more preferred than millet while groundnut (a legume) was the least preferred food (Fig. 6). Posthoc test also showed a significant

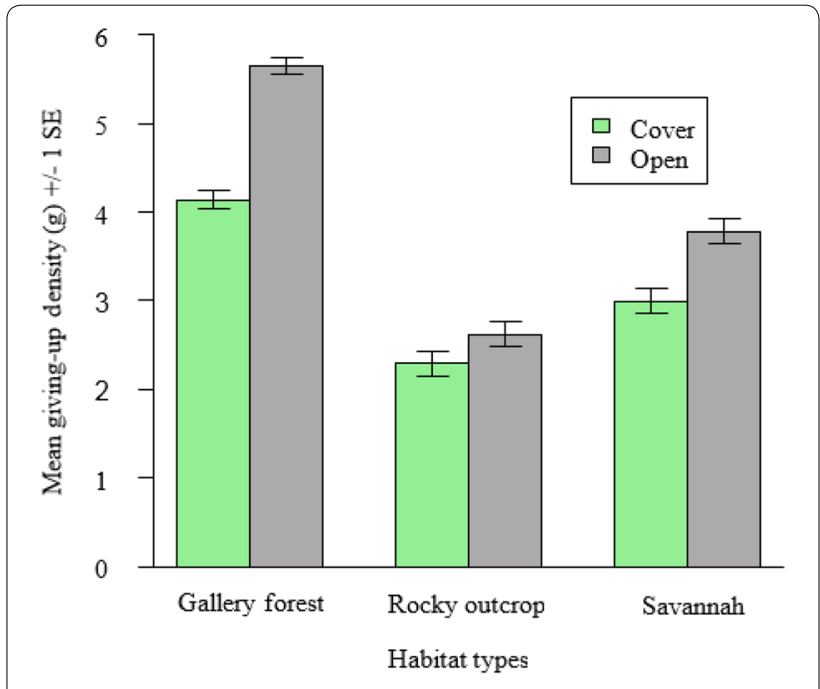

Fig. 3 Difference in GUDs between microhabitats of habitats 


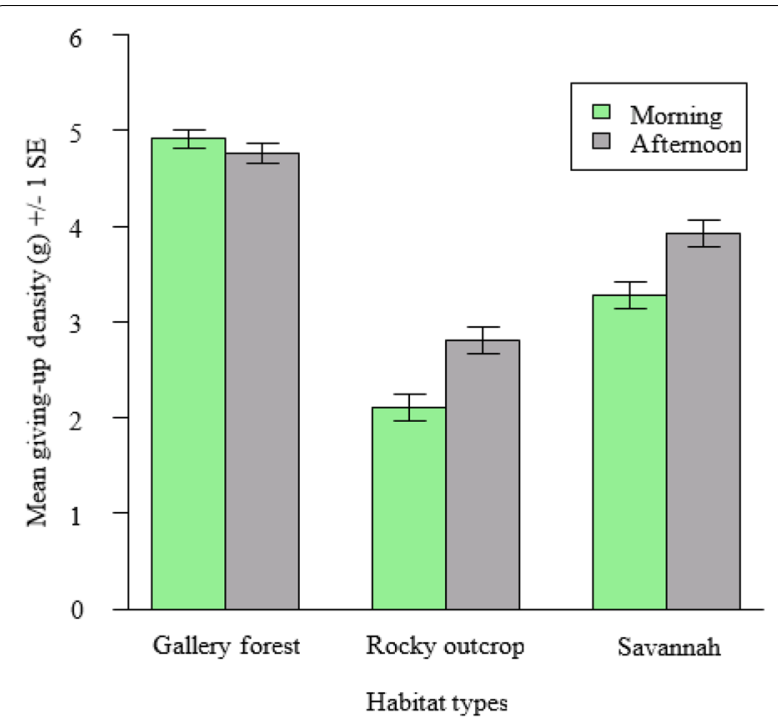

Fig. 4 Difference in GUDs between habitat types by times of day

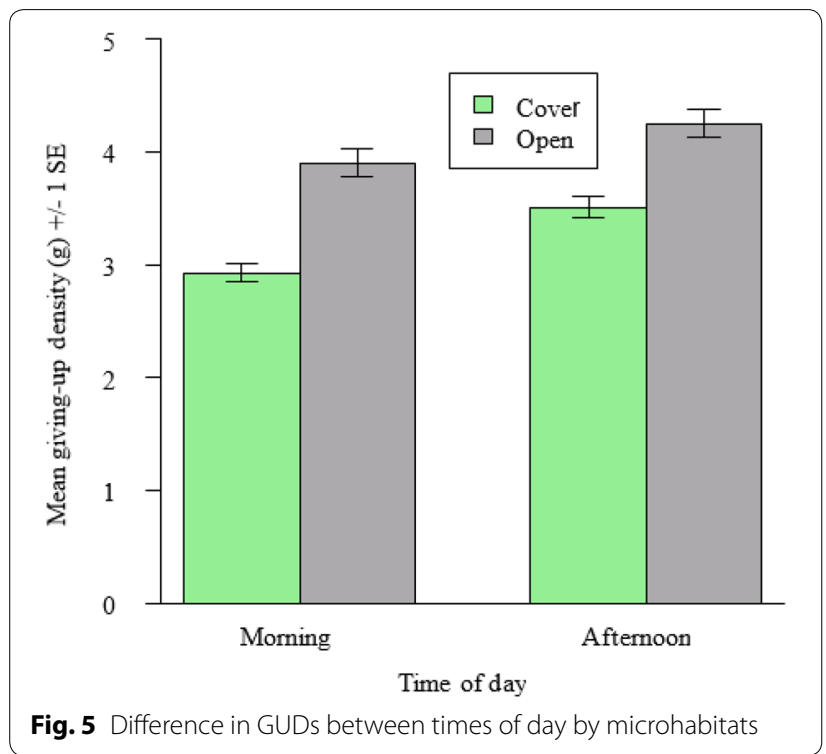

difference in pairwise comparisons between food types (Table 2).

\section{Bird visitors}

A total of 15 granivorous bird species were observed to have fed on the artificial food patches at different frequencies. They include Red-cheeked Cordon Bleu (Uraeginthus bengalus), Village Weaver (Ploceus cucullatus), Red-billed Firefinch (Lagonosticta senegala), Rock Firefinch (Lagonosticta sanguinodorsalis), Pin-tailed Whydah (Vidua macroura), Cinnamon-breasted Rock Bunting (Emberiza tahapisi), Black-rumped Waxbill (Estrilda

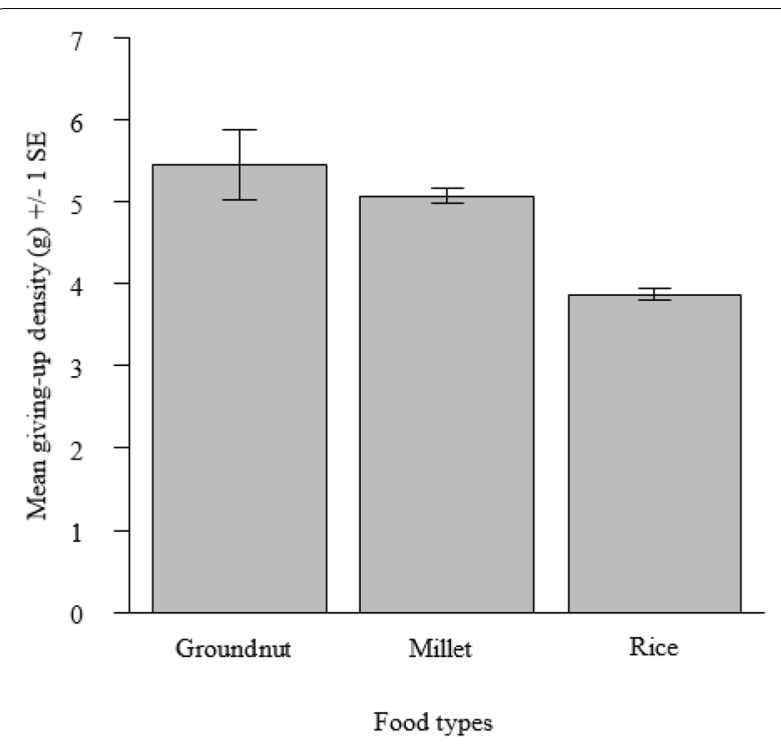

Fig. 6 Difference in GUDs between food types

troglodytes), Orange-cheeked Waxbill (Estrilda melpoda), Lavender Waxbill (Estrilda caerulescens), Northern greyheaded Sparrow (Passer griseus), Northern Red Bishop (Euplectes franciscanus), Bronze Mannikin (Spermestes cucullatus), Laughing Dove (Streptopelia senegalensis), Speckle-fronted Weaver (Sporopipes frontalis), and Sun Lark (Galerida modesta).

\section{Discussion}

\section{Predation and habitat quality}

The higher GUD in the open than the cover microhabitat in all three habitats (Fig. 3) support the idea that predation risk is higher in the open than in cover and that vegetation serves as a shelter from predators (Lomas et al. 2014). The vulnerability of foragers to predation in open areas means that they have to avoid becoming food for other animals while foraging, thereby making patches in the 'cover' more thoroughly exploited. However, areas with more 'cover' or dense vegetation also offer hideouts for ground predators. For example, the presence of lurking ground predators like snakes often observed in the Amurum Forest Reserve is a predominant feature in the tropics (Tobias et al. 2013). Thus, whereas these areas offer cover from avian predators, they could potentially be perceived as risky as that by snakes. This pattern concurs with many studies that have found support for a high GUD resulting from increased predation risk (Brown and Kotler 2004; Eccard et al. 2008) and reduced foraging activity in risky or open areas (Shochat et al. 2004; Cresswell 2008). Other studies which support this result include the study of granivorous birds in 
Amurum Forest Reserve (Molokwu et al. 2008), a study on White-footed Mice (Peromyscus leucopus) (Morris and Davidson 2000) and a study on Starlings (Sturnus vulgaris) (Olsson et al. 2002). Also, the metabolic cost of foraging may be higher in the open than cover due to heat exposure.

Generally, there was less intense feeding activity in the gallery forests compared to savannah and rocky outcrops respectively. Foraging theory predicts that relatively higher GUDs should be expected in good quality habitats (Brown and Kotler 2004); potentially due to the high cost of missed opportunities to forage elsewhere/ high potential costs of predation. The theory should have implied that the gallery forest is best in terms of quality (food availability). However, this may not be the case as the utilization of artificial food patches in the gallery forest may have been incidental. Small passerine birds are known to exhibit a characteristic pattern of daily foraging activity: feeding being generally peak in the morning, light through the mid-day and moderate to peak again before going to rest in late afternoon (Bonter et al. 2013). During these peak foraging windows, birds will prefer to select and use patches where food resources are highest (Saracco et al. 2004). For granivorous birds, therefore, gallery forest will not be an ideal habitat for foraging in the mornings. Birds usually use the gallery forest for resting and staying away from the heat of the day after an active foraging time in the morning. Of the other two habitats, savannah habitat quality is better than the rocky outcrop judging from the higher GUDs.

Lower GUDs recorded in the morning than afternoon for rocky outcrops and savannah (Fig. 4) suggests that during the peak of foraging in the morning (Bonter et al. 2013), the birds were basically opting to utilize patches (habitats) where their food resources are likely to be in high abundance. While seeking to rest in the shade to avoid the sun's heat after the day's active foraging in late afternoon, the birds made their way to the gallery forest where they got the opportunity to feed on the food patches there rather minimally. The perception of high predation risk (Olsson et al. 2002) and maximization of foraging period (Wolf and Hainsworth 1977) in birds are potential factors responsible for the differences in GUDs between times of day.

The consistent preference for cereal grains may have been influenced by nutritional content (Karasov and Martinez del Rio 2007). Rice has been shown to have a higher energy value than millet (Odoemelam and Osu 2009). Seed size is also a major factor that determines the extent of selection or rejection (Collins and Horn 2012). However, this is not the case in this study since all seeds used were crushed to approximately millet seeds sizes being the control with the smallest average size to ensure similar handling times.

Of all the food types provisioned, groundnut $(49.2 \mathrm{~g}$ per $100 \mathrm{~g}$ portion) has the highest fat content compared to millet ( $3.3 \mathrm{~g}$ per $100 \mathrm{~g}$ portion) and rice $(1 \mathrm{~g}$ per $100 \mathrm{~g}$ portion). Studies have shown that birds maintain daily fat levels in an effort to avoid predators (Tvardíková and Fuchs 2011; Zimmer et al. 2011). On the contrary, other studies have also shown that being too fat is also not good to escape predators (McNamara and Houston 1990; Witter and Cuthill 1993). The least preference for groundnut could also be explained by its high secondary compounds component which inhibits specific biochemical reaction (Schmidt et al. 1998) or reduces internal digestion in birds (Deshpande 2002). Tannins, for instance, is known to reduce the digestibility of proteins, and phytic acids may hinder intestinal absorption of certain nutrients like Magnesium and Calcium besides the limitation of starch and protein digestibility (Deshpande 2002; Odoemelam and Osu 2009). Seeds with high phenolic component have been found to be avoided by Bullfinches (Pyrrhula pyrrhula) (Greig-Smith and Wilson 1985), and seeds with quinine content, no matter how little can be sensed and declined by Cockatiels (Nymphicus hollandicus) (Matson et al. 2004).

Five bird records (the Pin-tailed Whydah Vidua macroura, Black-rumped Waxbill Estrilda troglodytes, Northern Grey-headed Sparrow Passer griseus, Bronze Mannikin Spermestes cucullatus, Laughing Dove Streptopelia senegalensis) were new compared to an earlier study conducted in the reserve in 2004 and 2005 which recorded a total of 10 bird visitors (Molokwu et al. 2008). Giving only one food type (millet) was placed in the earlier study, the new records of bird visitors we had could have been as a result of the different food types we provisioned or it could be that the fire outbreak that occurred just before we commenced our experiment had negative effects on the availability of natural seeds, thus making our experimental feeding stations more important.

\section{Potential fire effect on GUDs}

Just before the onset of the rains (and when the experiment started), the Amurum Forest Reserve experienced severe fire outbreaks which could have affected seed availability for the birds. The most affected habitats were the savannah and rocky outcrops. Although we did not test the effect of fires on seed availability between habitat types, the relatively lower GUDs in the savannah and rocky outcrops than in the gallery forest could be attributed to the fire incidence. Late intense fires have been shown to not only remove the dense grasses and dictate immediate/forthcoming food availability but also destroy most of the fallen seeds with adverse long term effects 
(Legge et al. 2015). Even though fire is an important feature of the dry season tropical savannah biome, we highly recommend that an early control burning regime be adopted at the onset of dry season to curb incessant and intensive fire outbreaks later. To better delineate the effect of fire on habitat quality for granivorous birds, future studies should consider doing a similar experiment post-fire outbreaks and should span both rainy and dry seasons.

\section{Conclusion}

This study demonstrates that by assessing the usage of artificial food patches by granivorous birds, we can gather a lot of information about the cost and benefit associated with a foraging area. Thus, it is possible to use this information as a proxy of habitat quality since the cost and benefit of foraging are habitat-specific. We show that habitat structure plays a very important role in shaping the behavior of birds on artificial food patches as evidenced from the high preference for 'cover' compared to 'open' microhabitats across all habitat types. The feeding activity of the birds at habitat and microhabitat levels is modulated by times of the day. Food preference was likely a factor of nutritional composition (energy content) and digestibility. The results from this study suggest that all the component habitat types of the Amurum Forest Reserve are important for the conservation of its granivorous birds; as each of the habitats supports their daily activities.

\section{Acknowledgements}

We would like to thank two anonymous reviewers for helpful comments on a previous version of this manuscript.

\section{Authors' contributions}

UAA conceived and designed the experiment with the valuable suggestions of STO and JA. UAA conducted the experiment, analyzed the data, and composed the manuscript. STO and JA made substantial contributions with results interpretation and helpful comments on the write-up. All authors read and approved the manuscript.

\section{Funding}

This work was funded by the Leventis Conservation Foundation and it is publication number 148 from the A.P. Leventis Ornithological Research Institute, Jos, Nigeria.

\section{Availability of data and materials}

Available with the corresponding author on reasonable request.

\section{Ethics approval and consent to participate}

Not applicable.

\section{Consent for publication}

Not applicable.

\section{Competing interests}

The authors declare that they have no competing interests.

\section{Author details}

${ }^{1}$ A. P. Leventis Ornithological Research Institute, University of Jos, Jos, Plateau State, Nigeria. ${ }^{2}$ Department of Watershed Sciences and the Ecology Center,
Utah State University, Logan, UT 84322-5210, USA. ${ }^{3}$ FitzPatrick Institute of African Ornithology, University of Cape Town, Rondebosch, Cape Town, South Africa.

Received: 14 November 2018 Accepted: 25 August 2019 Published online: 04 September 2019

\section{References}

Bolker BM, Brooks ME, Clark CJ, Geange SW, Poulsen JR, Stevens MH, et al. Generalized linear mixed models: a practical guide for ecology and evolution. Trends Ecol Evol. 2009;24:127-35.

Bonter DN, Zuckerberg B, Sedgwick CW, Hochachka WM. Daily foraging patterns in free-living birds: exploring the predation-starvation trade-off. Proc R Soc London B: Biol Sci. 2013;280:20123087.

Breckheimer I. Mapping habitat quality in conservation's neglected geography. Doctoral dissertation. Chapel Hill: The University of North Carolina; 2012.

Brown JS. Patch use as an indicator of habitat preference, predation risk, and competition. Behav Ecol Sociobiol. 1988;22:37-47.

Brown JS, Alkon PU. Testing values of crested porcupine habitats by experimental food patches. Oecologia. 1990;83:512-8.

Brown JS, Kotler BP. Hazardous duty pay and the foraging cost of predation. Ecol Lett. 2004;7:999-1014.

Burnham KP, Anderson DR. Model selection and multimodel inference: a practical information-theoretic approach. 2nd ed. New York: SpringerVerlag; 2002.

Charnov EL. Optimal foraging, the marginal value theorem. Theor Popul Biol. 1976;9:129-36.

Collins KA, Horn DJ. The role of oil content and size in seed selection by wild birds. Illinois State Acad Sci Trans. 2012;105(3/4):107.

Cresswell W. Non-lethal effects of predation in birds. Ibis. 2008;150:3-17.

Deshpande SS. Fungal toxins. In: Deshpande SS, editor. Handbook Food Toxicol. New York: Marcel Dekker Inc.; 2002. p. 413-7.

Dostine PL, Franklin DC. A comparison of the diet of three finch species in the Yinberrie Hills area, Northern Territory. Emu. 2002;102:159-64.

Eccard JA, Pusenius J, Sundell J, Halle S, Ylönen H. Foraging patterns of voles at heterogeneous avian and uniform mustelid predation risk. Oecologia. 2008; 157:725-34.

Ezealor AU. Critical sites for biodiversity conservation in Nigeria. Lekki: Nigerian Conservation Foundation; 2002

Greig-Smith PW, Wilson MF. Influences of seed size, nutrient composition and phenolic content on the preferences of bullfinches feeding in ash trees. Oikos. 1985;1:47-54.

Higginson AD, Fawcett TW, Trimmer PC, MCNamara JM, Houston Al. Generalized optimal risk allocation: foraging and antipredator behavior in a fluctuating environment. Am Nat. 2012;180:589-603.

Kamil AC, Krebs JR, Pulliam HR, editors. Foraging behavior. Berlin: Springer Science \& Business Media; 2012.

Karasov WH, del Rio CM. Physiological ecology: how animals process energy, nutrients, and toxins. Princeton: Princeton University Press; 2007.

Kelly JF. Population limitation in birds. Auk. 1999;116:866.

Kotler BP. Behavioral resource depression and decaying perceived risk of predation in two species of coexisting gerbils. Behav Ecol Sociobiol. 1992;30:239-444.

Legge S, Garnett S, Maute K, Heathcote J, Murphy S, Woinarski JC, et al. A landscape-scale, applied fire management experiment promotes recovery of a population of the threatened Gouldian Finch, Erythrura gouldiae, in Australia's Tropical Savannas. PLoS ONE. 2015;10:e0137997.

Lemon WC. Fitness consequences of foraging behavior in the zebra finch. Nature. 1991;352:153.

Lomas SC, Whisson DA, Maguire GS, Tan LX, Guay PJ, Weston MA. The influence of cover on nesting red-capped plovers: a trade-off between thermoregulation and predation risk? Victor Nat. 2014;131:115.

Matson KD, Millam JR, Klasing KC. Cockatiels (Nymphicus hollandicus) reject very low levels of plant secondary compounds. Appl Anim Behav Sci. 2004:85:141-56.

McNamara JM, Houston Al. The value of fat reserves and the tradeoff between starvation and predation. Acta Biotheor. 1990;38:37-61. 
Molokwu M, Olsson O, Nilsson JÅ, Ottosson U. Seasonal variation in patch use in a tropical African environment. Oikos. 2008;117:892-8.

Morris DW, Davidson DL. Optimally foraging mice match patch use with habitat differences in fitness. Ecology. 2000;81:2061-6.

Mwansat GS, Lohdip YN, Dami FD. Activities of the AP Leventis, the West African foremost ornithological research center. Sci World J. 2011;6:9-12.

Newton I. Population limitation in birds. New York: Academic Press; 1998.

Pinheiro J, Bates D, DebRoy S, Sarkar D. nIme: linear and nonlinear mixed effects models. R package version 3.1-137; 2012. https://CRAN.R-proje ct.org/package=nlme. Accessed 15 May 2019.

Odoemelam SA, Osu Cl. Aflatoxin B1 contamination of some edible grains marketed in Nigeria. J Chem. 2009;6:308-14.

Olsson OL, Molokwu MN. On the missed opportunity cost, GUD, and estimating environmental quality. Israel J Ecol Evol. 2007;53:263-78.

Olsson O, Brown JS, Smith HG. Long-and short-term state-dependent foraging under predation risk: an indication of habitat quality. Anim Behav. 2002;63:981-9.

R Development Core Team. R: a language and environment for statistical computing. Version 2.15.1. Vienna, Austria: R Foundation for Statistical Computing; 2017. http://cran.rproject.org/. Accessed 20 Apr 2019.

Roff $D$, editor. Evolution of life histories: theory and analysis. Berlin: Springer Science \& Business Media; 1993.

Russell L, Jonathan L, Maxime H. emmeans: estimated marginal means, aka least-squares means. R package version 1.1.2; 2018. https://CRAN.Rproj ect.org/package=emmeans. Accessed 27 May 2019

Saracco JF, Collazo JA, Groom MJ. How do frugivores track resources? Insights from spatial analyses of bird foraging in a tropical forest. Oecologia. 2004;139:235-45.

Schielzeth $\mathrm{H}$. Simple means to improve the interpretability of regression coefficients. Methods Ecol Evol. 2010;1:103-13.
Schmidt KA, Brown JS, Morgan RA. Plant defenses as complementary resources: a test with squirrels. Oikos. 1998:81:130-42.

Shochat E, Lerman SB, Katti M, Lewis DB. Linking optimal foraging behavior to bird community structure in an urban-desert landscape: field experiments with artificial food patches. Am Nat. 2004;164:232-43.

Stankowich T, Blumstein DT. Fear in animals: a meta-analysis and review of risk assessment. Proc R Soc London B Biol Sci. 2005;272:2627-34.

Stearns SC. The evolution of life histories. Oxford: Oxford University Press; 1992.

Stephens DW, Krebs JR. Foraging theory. Princeton: Princeton University Press; 1986.

Tobias JA, Sekercioglu CH, Vargas FH. Bird conservation in tropical ecosystems: challenges and opportunities. Key Topics Conserv Biol. 2013;2:258-76.

Tvardíková K, Fuchs R. Do birds behave according to dynamic risk assessment theory? A feeder experiment. Behav Ecol Sociobiol. 2011;65:727-33.

Vickery J, Jones PJ. A new ornithological institute in Nigeria. Bull Afr Bird Club. 2002;9:61-2.

Wilmers CC, Nickel B, Bryce CM, Smith JA, Wheat RE, Yovovich V. The golden age of bio-logging: how animal-borne sensors are advancing the frontiers of ecology. Ecology. 2015;96:1741-53.

Witter MS, Cuthill IC. The ecological costs of avian fat storage. Phil Trans R Soc London B Biol Sci. 1993;340:73-92.

Wolf LL, Hainsworth FR. Temporal patterning of feeding by hummingbirds. Anim Behav. 1977;25:976-89.

Zimmer C, Boos M, Poulin N, Gosler A, Petit O, Robin JP. Evidence of the trade-off between starvation and predation risks in ducks. PLoS ONE. 2011;6:e22352.
Ready to submit your research? Choose BMC and benefit from:

- fast, convenient online submission

- thorough peer review by experienced researchers in your field

- rapid publication on acceptance

- support for research data, including large and complex data types

- gold Open Access which fosters wider collaboration and increased citations

- maximum visibility for your research: over $100 \mathrm{M}$ website views per year

At BMC, research is always in progress.

Learn more biomedcentral.com/submissions 